\title{
Assessment of the stability and loading indicators of two-axle mine cars and rail tracks
}

\author{
Volodymyr Hovorukha, ${ }^{1, *}$, and Todor Zhelyazov ${ }^{2}$ \\ ${ }^{1}$ Institute of Geotechnical Mechanics named by N. Poljakov of National Academy of Sciences of \\ Ukraine, 49005, Dnipro, Simferopolska Str., 2a, Ukraine \\ ${ }^{2}$ Technical University of Sofia, 1000, Sofia, Kliment Ohridski Blvd., 8, Bulgaria
}

\begin{abstract}
The paper presents the research results of the stability and loading of the two-axle mine cars and rail tracks with various design for calculation schemes construction of transport systems of underground rail haulage. The dependences of changes in loading, stability and operation safety of rolling stocks from the parameters of irregularities, curvature radii of the rail track and the movement speed of rolling stocks at various technical solutions of the transport system, have been studied. The research results of the interaction between the two-axle mine cars and rail track with the gauge of $750 \mathrm{~mm}$ for underground rail haulage are presented. The parameters have been determined of the rail track irregularities in the horizontal and vertical planes, which cause the highest values of vertical and horizontal loads, acting on the rail track and the two-axle rolling stock. The recommendations are proposed for improving the study of the rail vehicles and regulatory documents development for the construction and operation of the track structure. The results can be applied for the underground rail haulage when creating the new vehicles for mines.
\end{abstract}

\section{Introduction}

The two-axle mine cars performance capability functionally depends on the rail tracks working capability. The technical level of each vehicle determines the efficiency and performance of the transport system in general. Therefore, a change in the carrying capacity and mine cars design, as well as in operational requirements for the movement speed or load intensity of sites, predetermines the need to adjust the design of the rail track and its components.

The achievements analysis in the field of construction and improvement of new designs of two-axle rolling units and rail tracks [1-6] testifies that the certain changes have been made over the past decades in the rolling stock design. These changes include an increase in carrying capacity and rolling stock speed by $2-3$ times.

Over the specified period, there were no significant railway equipment changes in the designs of intermediate rail fastenings, sleepers and railroad switches. Regulatory requirements and regulatory-technical provisions have also remained unchanged. Due to the sharp nonconformity between the technical level of the rail track design and the

*Corresponding author: igtm.rail.trans@gmail.com 
rolling stock characteristics, the service life of the elements of rail track, sleepers, fasteners, etc. is equal to 1-3 years, instead of 6-8 years. Such a state of the railway equipment design leads to an increase of operating costs, and also to a violation of the work safety requirements on the rail haulage [2, 3, 6-8]. Development of the new elements of railway equipment and regulatory-technical documentation that specifies the design, construction and operation standards of the rail track including margin tolerances and regulations for deviations from the normative state is relevant. It is also necessary to resolve inconsistency of the rail track design technical level with the new technical characteristics of the rolling stock.

The purpose of this study is to assess the influence of the technical state of the rail track and rolling stock on the indicators of loading, stability and safety of the mine rail haulage.

The curvature radii values of the rail track at industrial mining enterprises are in the range of $8-50 \mathrm{~m}$ due to the difficult mining and geological conditions of operation. The rolling stocks have different engineering decisions for fastening the body, running gear and wheels due to the extremely small curvature radii and with the railway gauge of $750 \mathrm{~mm}$. The wheels of the running gear have the rigid mounting on the axles of wheelsets. In some designs, the wheels have free rotation on the axles.

In theoretical studies of the dynamic processes of the rolling stocks interaction with the rail track at the mining enterprises, simplifications were previously used based on the decision of the wheels' rigid mounting on the wheelsets axles [9-14]. Such simplifications are inexpedient in the case when the rolling stocks have free rotations on the wheelsets axles of the mine cars. Therefore, the study provides an assessment of stability and loading of the two-axle mine cars movement, taking into account the specifics of wheels fastening on the axles of wheelsets in accordance with the design features of the rolling units of the rolling stock under consideration. In addition, the margin tolerances should also be determined of the track rails irregularities in the plan and profile of the track trajectory.

The studies have been conducted for two-axle mine cars with free and rigid wheels' mounting on the wheelsets axles. The rail track is presented by straightway sections, easement and circular curves with irregularities of track rails in the horizontal and vertical planes. In the mechanics of the two-axle mine cars interaction with the rail tracks, these issues have not previously been considered.

\section{Methodology}

In order to assess the stability and loading indicators of the two-axle mine rolling units and the rail track of mine rail haulage, a number of coefficients should be determined. In particular, the movement stability coefficient under the conditions of wheel unloading, the stability coefficient during the wheelsets railing and the coefficients of resistance to the track panel shear. In addition, the load indicators determined by the maximum values of the vertical and horizontal forces, acting on wheels and rails depending on the parameters of horizontal and vertical irregularities of straightway and curved rail track sections, are also of great importance.

As objects of research, the two-axle mine cars with rigid and free wheels mounting on the axles of wheelsets are adopted. These include two-axle mine cars of the WG-4.5-750 type (weight is 16.7 tons). The rail track has the gauge of $750 \mathrm{~mm}$ and includes straightway sections, easement and circular curves with radii of $12 \mathrm{~m}, 20 \mathrm{~m}$ and $30 \mathrm{~m}$ with the track rails irregularities in horizontal and vertical planes.

Two-axle rolling units are represented by a mechanical system consisting of solids (body, frames, wheels, wheelsets) with rigid wheels mounting on the wheelsets axles. The mechanical system also may consist of axles of the wheelsets and wheels freely mounted on these axles, fastened by elastic-dissipative, rigid or jointed connections.

The calculation scheme of the two-axle rolling unit with free wheels rotating relative to 
the axles of wheelsets and with a rigid mounting of wheels on the axles of wheelsets is similar to the calculation scheme presented in the work [15].

In this case, the rail track under each wheel of the rail haulage is represented by a chain of solids in the vertical and transverse directions. Its main components (rails, rail support, sleepers and under-sleeper base), interconnected by elastic-dissipative elements in the vertical and transverse directions, are considered. In addition, the viscous resistance, proportional to the relative speed of solids displacement and dry friction between the bodies are also taken into consideration in this transport system. There are also options when the rail track is represented by one reduced solid in the vertical and transverse directions, which is attached to each wheel through generalized elastic-dissipative bonds.

To assess the stability and loading indicators of two-axle mine cars and rail tracks, the dynamic processes of the studied transport system interaction are studied using the method given in the work [15].

The basic initial data and calculated characteristics for the studied transport system are the following:

- mine car body weight (with load) is 16.7 tons;

- wheelset axle weight is 0.161 tons;

- wheel weight is 0.083 tons;

- reduced masses of track rails in the horizontal and vertical directions are 0.05 tons and 0.13 tons, respectively;

- static load on the wheel is $43.5 \mathrm{kN}$;

- distance between the truck centers of the mine car is $1.25 \mathrm{~m}$;

- distance between the elastic elements axles of the body bearing on the wheelsets axle in the horizontal direction is $0.46 \mathrm{~m}$;

- height of the body gravity center above the plane of elastic elements is $0.41 \mathrm{~m}$;

- average radius of the wheels rolling circle is $0.2 \mathrm{~m}$;

- distance between the wheels rolling circles is $0.797 \mathrm{~m}$;

- gap clearance between the wheel flange and the rail head is $0.01 \mathrm{~m}$;

- elastic elements rigidity between the body and the wheelset in the longitudinal, horizontal and vertical directions are $2140 \mathrm{kN} / \mathrm{m}, 2140 \mathrm{kN} / \mathrm{m}$ and $4280 \mathrm{kN} / \mathrm{m}$, respectively;

- viscous resistance coefficients of the mine car dampers in the longitudinal, horizontal and vertical directions are $20 \mathrm{kN} \cdot \mathrm{s} / \mathrm{m}, 20 \mathrm{kN} \cdot \mathrm{s} / \mathrm{m}$ and $40 \mathrm{kN} \cdot \mathrm{s} / \mathrm{m}$, respectively;

- dry friction forces in the mine car dampers in the longitudinal, horizontal and vertical directions are $1 \mathrm{kN}, 1 \mathrm{kN}$ and $2 \mathrm{kN}$, respectively;

- reduced rigidities of the track rails in the horizontal and vertical directions are $14340 \mathrm{kN} / \mathrm{m}$ and $20100 \mathrm{kN} / \mathrm{m}$, respectively;

- reduced coefficients of the dampers viscous resistance of track rails in the horizontal and vertical directions are $20 \mathrm{kN} \cdot \mathrm{s} / \mathrm{m}$ and $10 \mathrm{kN} \cdot \mathrm{s} / \mathrm{m}$, respectively;

- reduced dry friction forces in the dampers of track rails in the horizontal and vertical directions are $6 \mathrm{kN}$ and $4 \mathrm{kN}$, respectively;

- wheelset weight in case of rigid wheels mounting is 0.327 tons;

- reduced masses of track rails in the horizontal and vertical directions are 0.05 tons and 0.13 tons, respectively;

- reduced masses of sleepers in the horizontal and vertical directions are 0.04 tons and 0.1 tons, respectively;

- reduced masses of sleeper base in the horizontal and vertical directions are 0.2 tons and 0.3 tons, respectively;

- reduced rigidities of track rails in the horizontal and vertical directions are $70 \mathrm{MN} / \mathrm{m}$ and $90 \mathrm{MN} / \mathrm{m}$, respectively;

- viscous resistance coefficients of bracings in the horizontal and vertical directions are $20 \mathrm{kN} \cdot \mathrm{s} / \mathrm{m}$ and $10 \mathrm{kN} \cdot \mathrm{s} / \mathrm{m}$, respectively;

- dry friction forces of dampers in the bracing in the horizontal and vertical directions 
are $6 \mathrm{kN}$ and $4 \mathrm{kN}$, respectively;

- sleeper base rigidity in the horizontal and vertical directions are $22 \mathrm{MN} / \mathrm{m}$ and $33 \mathrm{MN} / \mathrm{m}$, respectively;

- viscous resistance coefficients of the sleeper base dampers in the horizontal and vertical directions are $20 \mathrm{kN} \cdot \mathrm{s} / \mathrm{m}$ and $10 \mathrm{kN} \cdot \mathrm{s} / \mathrm{m}$, respectively;

- dry friction forces of the sleeper base in the horizontal and vertical directions are $4 \mathrm{kN}$ and $3 \mathrm{kN}$, respectively;

- reduced rigidity of the rail base in the horizontal and vertical directions are $100 \mathrm{MN} / \mathrm{m}$ and $120 \mathrm{MN} / \mathrm{m}$, respectively;

- viscous resistance coefficients of the rail base dampers in the horizontal and vertical directions are $30 \mathrm{kN} \cdot \mathrm{s} / \mathrm{m}$ and $15 \mathrm{kN} \cdot \mathrm{s} / \mathrm{m}$, respectively;

- dry friction forces of the rail base in the horizontal and vertical directions are $5 \mathrm{kN}$ and $2 \mathrm{kN}$, respectively.

The elastic-dissipative bonds between the mine car body and running gears in the main directions of loads action and the displacements (deformations) formation in the horizontal and vertical planes are characterized by the elasticity, viscous resistance and dry friction. The wheels rolling surface is characterized by a nonlinear function. The tangential forces of wheels and rails interaction correspond to the creep hypothesis with account of nonlinear dependences from the dimensionless characteristics of wheel sliding against rails. The wheels rolling profile is characterized by certain constants that correspond to the wheels' profile parameters according to works $[12,13,15]$.

On the one hand, the rail track is assumed in the form of three discrete concentrated masses (rails, sleepers, base) connected to each wheel by means of elastic-dissipative bonds set sequentially in the vertical and transverse directions. On the other hand, the rail track is represented in the form of a single track mass reduced to each wheel in the vertical and transverse directions with the help of those elastic-dissipative bonds.

Track rail irregularities in the plan are specified in the form of a cosine wave or sine wave with various parameters of their length and depth. Joint vertical irregularities are specified in the form of a cosine wave with limited length within one its period and in the form of complex irregularities with various parameters of their length and depth, according to works [12-15].

The transport systems loading and stability have been assessed according to indicators characterizing the loading of separate parts of the mine cars and rail tracks in the vertical and transverse directions. Indicators of stability and movement safety, as well as coefficients of resistance to wheels unloading, resistance to wheelsets railing, and resistance to the track panel shear, are equally significant in the assessment.

The maximum values of forces acting on the wheels, spring groups and track rails in the vertical and transverse directions, as well as the transverse forces acting on the wheelsets are criteria for assessing the dynamic indexes of the mine cars under study.

\section{Results and discussion}

Based on the research result, the main dependency graphs have been obtained of loading, vibration, stability and safety indicators of the two-axle mine car WG-4.5-750 type movement. These curves depend on the changes in the track curvature radii, the length of vertical and transverse (horizontal) irregularities and their depth value, as well as on the mine car speed for various two-axle mine car calculation schemes. A variety of calculation schemes is determined by the detail degree, that is, each wheelset can be represented by one solid body, otherwise each axle and two wheels with free rotation can be represented by three solids. In its turn, the rail track can be represented either in the form of three discrete concentrated masses or by combined track structure in the form of a single track mass. 
Figure 1 shows the dependency graphs of the mine car body displacements in the vertical and transverse planes depending on the straightway section length of the rail track. Vibration processes, such as chattering and lateral motion of the mine car body, occur at a rail track section under study.

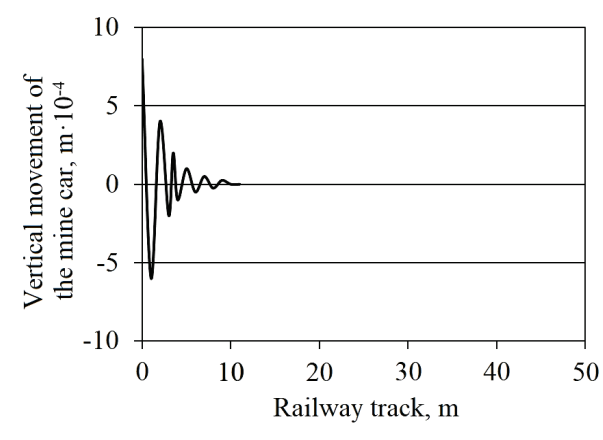

a

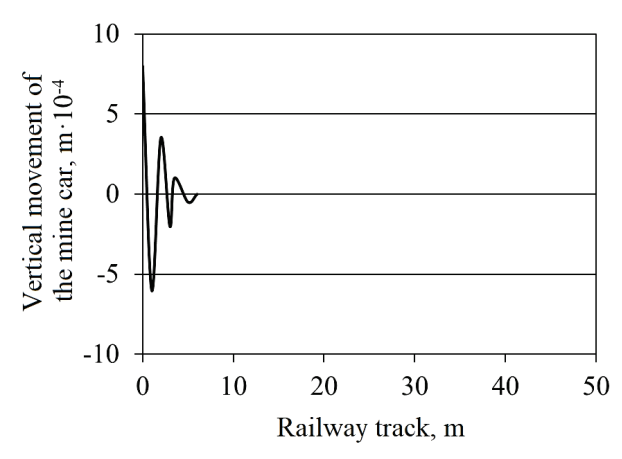

$\mathrm{c}$

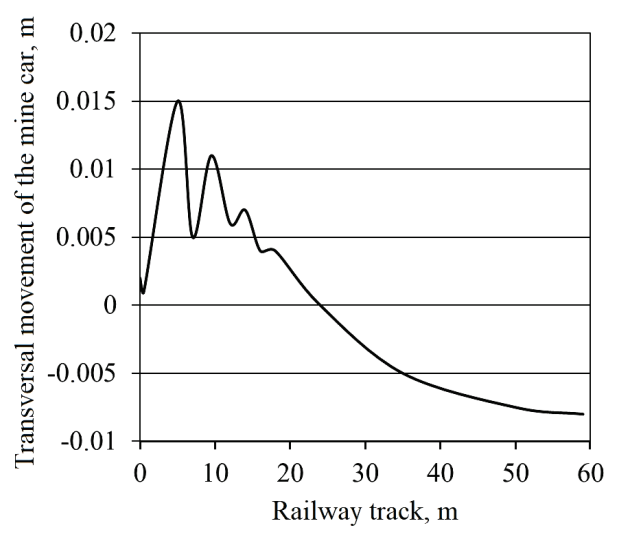

b

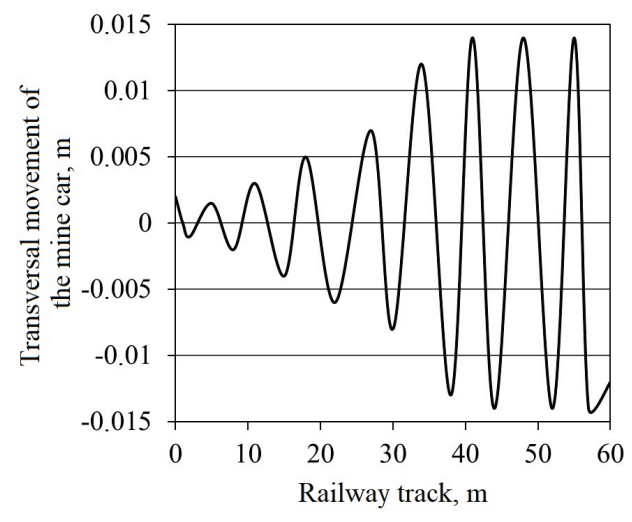

d

Fig. 1. Vertical and transversal displacements of the mine car body relative to the geometric axles in case of free and rigid wheels mounting: $a$ and $b$ - free mounting of wheels on the wheelsets axles; $\mathrm{c}$ and $\mathrm{d}$ - rigid mounting of wheels on the wheelsets axles.

Figures $1, \mathrm{a}$ and $1, \mathrm{~b}$ show the vertical and transversal displacements of the mine car body with free wheel mounting on the wheelsets axles. For a comparative analysis, Figures 1, c and 1, d also show the vertical and transversal displacements of the mine car body, where there is a rigid wheel mounting on the wheelsets axles.

Comparative analysis of vibration amplitudes parameters of the mine car body WG-4.5-750 type shows quick attenuation in the amplitudes of vertical vibration (chattering) in the cases of free and rigid wheels mounting (see Figures 1, a and 1, c). Transversal vibrations with free mounting of wheels on the axles are also accompanied by attenuation (see Figure 1, b), that is, the mine car movement is stable. When the wheels are rigidly mounted on the axle, an intense increase in vibrations occurs (see Figure 1, d), hence, the mine car movement is unstable. Therefore, in case of the mine car interaction with the rail track elements, significant displacements and forces of interaction in the transverse plane are possible.

In this case, the wheelsets at a curved section are set in the position, in which the wheel of the front wheelset, rolling along the outer rail, and the wheel of the rear wheelset, rolling 
along the inner rail, touch periodically the rail heads by flanges or the wheels' fillets. Moreover, the outer track rail has a significantly greater displacement than the inner one.

The distinctive feature of the mine car movement with the wheels mounted rigidly is the case, when the wheelsets are set in the chordal position at a curved section. As for the mine car with free rotation of wheels, the wheelsets are set in the position approaching the state of greatest tilt.

As can be seen from the above, the movement quality from the condition of its stability and steady-state modes of motion at curved sections for both calculation schemes can be different. Therefore, when choosing for research of the rail haulage calculation schemes, it is necessary to take into account design features of mounting the wheels on their rotation axles. This finding is relevant since in the previous studies these mine car design features were not considered (the wheels and the wheelset axles were represented by one solid body).

The research results of dynamic indexes of loading and stability of the two-axle mine car WG-4.5-750 type movement with free and rigid wheels mounting on the wheelsets axles are given in the summary tables. Table 1 characterizes the indicators of loading, stability and safety of the mine car movement with free and rigid mounting of wheels on the axles in case of forced vibrations. The latter are caused by periodic irregularities of the rail track, where vertical cosine irregularities have the length of $2 \mathrm{~m}$ and the depth of $0.01 \mathrm{~m}$. Horizontal sinusoidal irregularities have the length within one period of $3 \mathrm{~m}$ and the depth of $0.03 \mathrm{~m}$. The straightway and curved sections of the track with a radius of $30 \mathrm{~m}$ are studied.

Table 1. Characteristics of loading, stability and safety of the two-axle mine cars movement for various designs of the wheels mounting on the wheelsets axles.

\begin{tabular}{|l|c|c|c|c|}
\hline \multirow{2}{*}{ Characteristics } & \multicolumn{4}{|c|}{ Rail track section } \\
\cline { 2 - 5 } & \multicolumn{2}{|c|}{ Straightway section } & \multicolumn{2}{c|}{$\begin{array}{c}\text { Curved rail section with } \\
\text { a radius of 30 m }\end{array}$} \\
\cline { 2 - 5 } & $\begin{array}{c}\text { Free } \\
\text { mounting of } \\
\text { wheels on } \\
\text { the axle }\end{array}$ & $\begin{array}{c}\text { Rigid } \\
\text { mounting of } \\
\text { wheels on } \\
\text { the axle }\end{array}$ & $\begin{array}{c}\text { Free } \\
\text { mounting of } \\
\text { wheels on } \\
\text { the axle }\end{array}$ & $\begin{array}{c}\text { Rigid } \\
\text { mounting of } \\
\text { wheels on } \\
\text { the axle }\end{array}$ \\
\hline Vertical loads on wheels, kN & 82.0 & 80.7 & 85.8 & 90.0 \\
\hline Transverse loads on wheelsets, kN & 59.2 & 57.3 & 78.1 & 86.3 \\
\hline Vertical loads on rails, kN & 83.3 & 82.0 & 87.1 & 91.2 \\
\hline Transverse loads on rails, kN & 58.1 & 51.4 & 78.8 & 86.1 \\
\hline $\begin{array}{l}\text { Transverse loads on the elastic } \\
\text { elements of the mine car buffer } \\
\text { springs, kN }\end{array}$ & 40.4 & 37.5 & 64.5 & 74.4 \\
\hline $\begin{array}{l}\text { Vertical loads on the elastic } \\
\text { elements of the mine car buffer } \\
\text { springs, kN }\end{array}$ & 74.9 & 72.9 & 89.6 & 92.7 \\
\hline $\begin{array}{l}\text { Coefficients of resistance to wheels } \\
\text { railing }\end{array}$ & 1.07 & 1.17 & 0.85 & 0.75 \\
\hline $\begin{array}{l}\text { Coefficients of resistance to wheels } \\
\text { unloading }\end{array}$ & 0.64 & 0.66 & - & - \\
\hline $\begin{array}{l}\text { Coefficients of resistance to the rail } \\
\text { track shear }\end{array}$ & 0.75 & 0.71 & 1.27 & 1.56 \\
\hline
\end{tabular}

The calculation results have revealed that at a straightway track section, most of the indicators of loading running gears and spring groups of the mine car, as well as loading the track have close values. Given the loading and safety indicators in curved sections of the track with a radius of $R=30 \mathrm{~m}$, the movement of the mine car with freely rotating wheels is better. Moreover, the difference in performance reaches $20 \%$. Therefore, for the forced vibrations analysis, the rail haulage calculation schemes should be selected taking into account design features with wheels mounted on the 
wheelsets axles.

Table 2 characterizes the indicators of loading, stability and safety of the two-axle mine cars movement with the wheels' free rotation on the wheelsets axels at a speed of $5 \mathrm{~m} / \mathrm{s}$ along the straightway and curved sections of the rail track. The rail track involves irregularities with the multi-mass track structure (rails, sleepers, base) and the single-mass track reduced to one solid body.

Table 2. Characteristics of loading, stability and safety of the two-axle mine cars movement for various rail track schemes.

\begin{tabular}{|l|c|c|c|c|}
\hline \multirow{2}{*}{ Characteristics } & \multicolumn{4}{|c|}{ Rail track section } \\
\cline { 2 - 5 } & \multicolumn{2}{|c|}{ Straightway section } & $\begin{array}{c}\text { Curved rail section with } \\
\text { a radius of 30 m }\end{array}$ \\
\cline { 2 - 5 } & $\begin{array}{c}\text { Multi- } \\
\text { mass track }\end{array}$ & $\begin{array}{c}\text { Reduced } \\
\text { mass of the } \\
\text { track }\end{array}$ & $\begin{array}{c}\text { Multi- } \\
\text { mass track }\end{array}$ & $\begin{array}{c}\text { Reduced } \\
\text { mass of the } \\
\text { track }\end{array}$ \\
\hline Vertical loads acting on wheels, kN & 84.1 & 82.0 & 88.6 & 85.8 \\
\hline Transverse loads on wheelsets, kN & 58.9 & 58.9 & 80.2 & 78.1 \\
\hline Vertical loads acting on rails, kN & 85.3 & 83.3 & 89.9 & 87.1 \\
\hline $\begin{array}{l}\text { Transverse loads on the elastic } \\
\text { elements of the mine car buffer } \\
\text { springs, kN }\end{array}$ & 38.6 & 40.4 & 64.1 & 64.5 \\
\hline $\begin{array}{l}\text { Vertical loads on the elastic } \\
\text { elements of the mine car buffer } \\
\text { springs, kN }\end{array}$ & 75.8 & 74.9 & 94.1 & 92.8 \\
\hline $\begin{array}{l}\text { Coefficients of resistance to wheels } \\
\text { railing }\end{array}$ & 1.07 & 1.07 & 0.82 & 0.85 \\
\hline $\begin{array}{l}\text { Coefficients of resistance to wheels } \\
\text { unloading }\end{array}$ & 0.75 & 0.68 & - & - \\
\hline $\begin{array}{l}\text { Coefficients of resistance to the rail } \\
\text { track shear }\end{array}$ & 0.85 & 0.74 & 1.42 & 1.27 \\
\hline
\end{tabular}

The comparative assessment of the calculation schemes for a multi-mass rail track and a single-mass rail track shows that the indicators differ by $5.3 \%$ according to the conditions of the mine cars and rail track loading and by $10.6 \%$ according to the movement safety condition.

Loading and safety of the mine car movement was assessed with account of deviations from the track design position. These deviations are conditioned by vertical irregularities described by the cosine wave within one period and by transverse irregularities of the rail track axel represented by the continuous sinusoidal wave.

Figures 2 and 3 show dependency graphs for indicators of loading, stability and safety of the mine car WG-4.5-750 type movement from the length of vertical irregularities with various depths of these irregularities. The mine car moves with a speed of $5 \mathrm{~m} / \mathrm{s}$ along the curved section $(R=30 \mathrm{~m})$ of the rail track and its wheels have free rotation on the wheelsets axels.

It has been determined that the maximum values of the forces acting on the elements of the "mine car - rail track structure" transport system, as well as the values of wheels unloading coefficients and resistance to the track panel shear, vary insignificantly in the range of vertical irregularities length values from 4 to $10 \mathrm{~m}$ at curved track sections. With a decrease in the length of irregularities from 4 to $1 \mathrm{~m}$, there is a sharp increase in all studied indicators of loading and stability with their reaching of maximum when the irregularities length is equal to $1-2 \mathrm{~m}$ and their depth is more than $0.01 \mathrm{~m}$. Such a change in the indicators is conditioned by an increase in centrifugal forces when the rail track profile is changed due to its subsidence, shears, accumulation of residual deformations, as well as forced vertical and transversal displacements and forced mine car vibrations during 
chattering and lateral motion. Therewith, the forced vibrations of mine car when moving through irregularities of 1-2 m long (see Figures 4 and 5) have a certain periodic nature. Their frequency is about $1 \mathrm{~Hz}$ for straightway sections (see Figure 4) and about $1.33 \mathrm{~Hz}$ for curved sections (see Figure 5). The natural mine car body vibrations are $1.1 \mathrm{~Hz}$ for straightway sections and $1.4 \mathrm{~Hz}$ for curved sections.

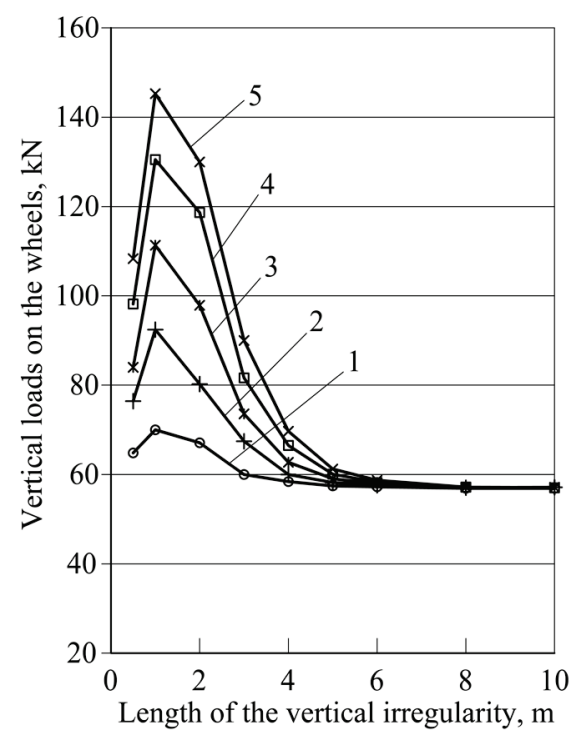

a

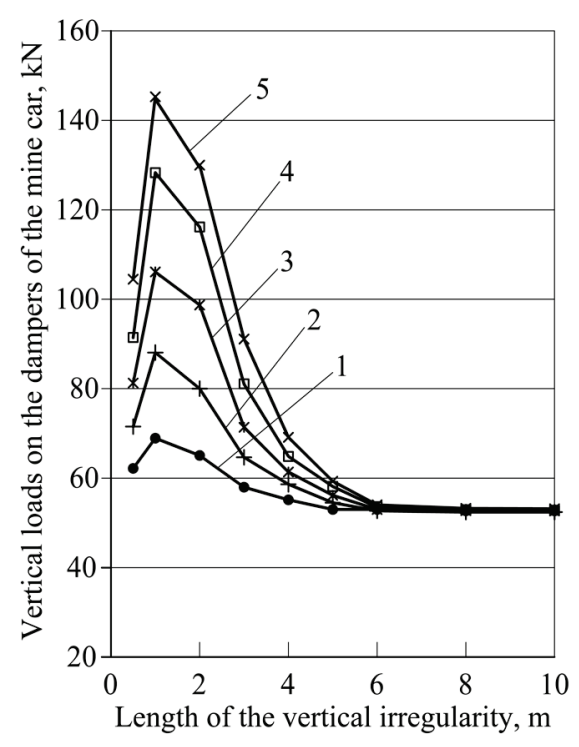

$\mathrm{c}$

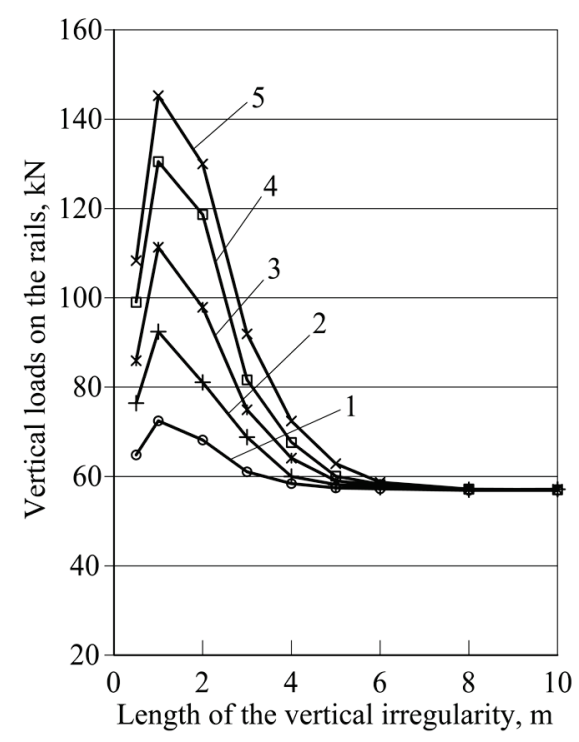

b

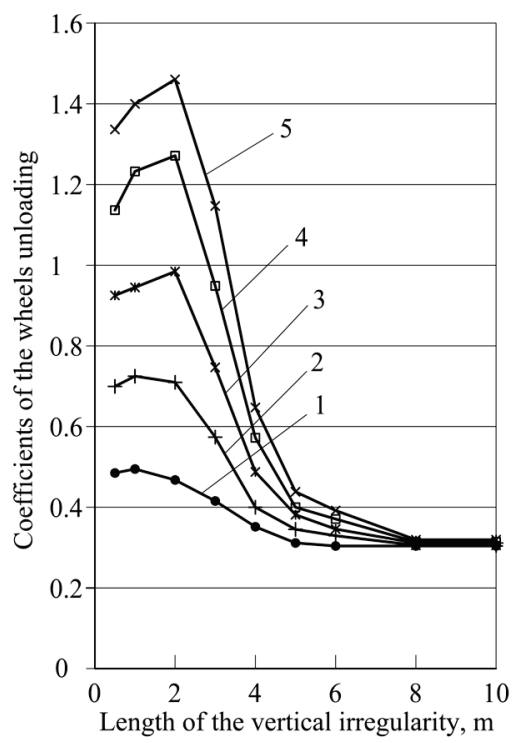

d

Fig. 2. Dependences of maximum values of the vertical loads and wheels unloading coefficients on the vertical irregularity length of the curved rail track: a - vertical loads on the wheel, $\mathrm{kN}$; $\mathrm{b}$ - vertical loads on the rails, $\mathrm{kN}$; $\mathrm{c}$ - vertical loads on the elastic elements of the mine car, $\mathrm{kN}$; $\mathrm{d}$ - coefficients of the wheels unloading; $1,2,3,4,5,6$ - depths of the vertical irregularities of $0.005,0.010,0.015,0.020,0.030$ and $0.060 \mathrm{~m}$, respectively. 


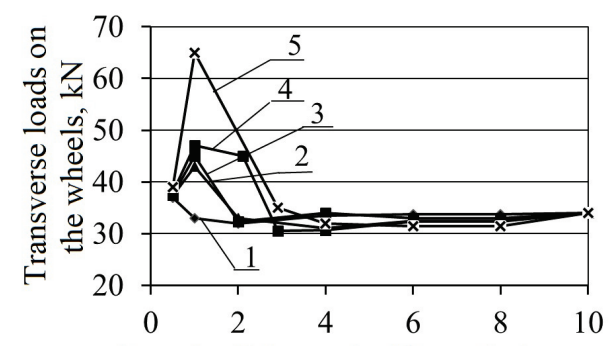

Length of the vertical irregularity, $\mathrm{m}$

a

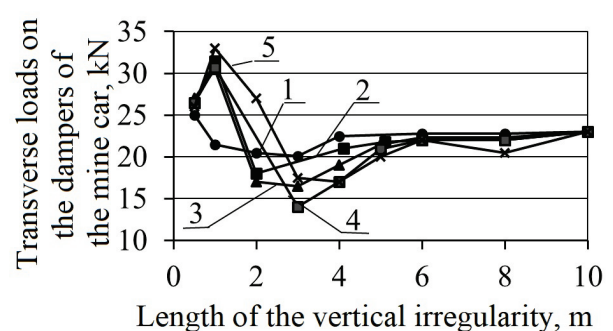

c

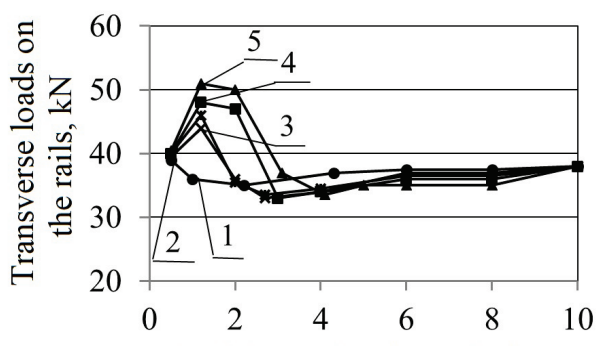

Length of the vertical irregularity, $m$ $\mathrm{b}$

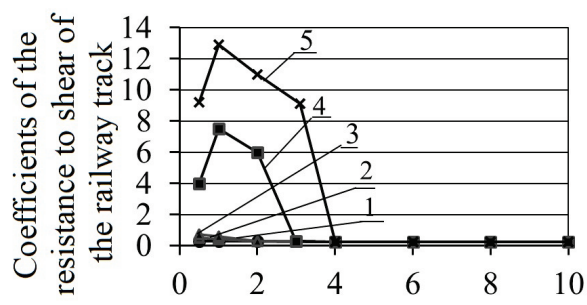

Length of the vertical irregularity, $\mathrm{m}$

d

Fig. 3. Dependences of maximum values of the transverse loads and coefficients of resistance to the rail track shear on the vertical irregularities length of the curved rail track: a - transverse loads on the wheels, $\mathrm{kN} ; \mathrm{b}$ - transverse loads on the rails, $\mathrm{kN} ; \mathrm{c}$ - transverse loads on the elastic elements of the mine car, $\mathrm{kN}$; $\mathrm{d}$ - coefficients of resistance to the rail track shear; 1, 2, 3, 4, 5, 6-depth of the vertical irregularities of $0.005,0.010,0.015,0.020,0.030$ and $0.060 \mathrm{~m}$, respectively.

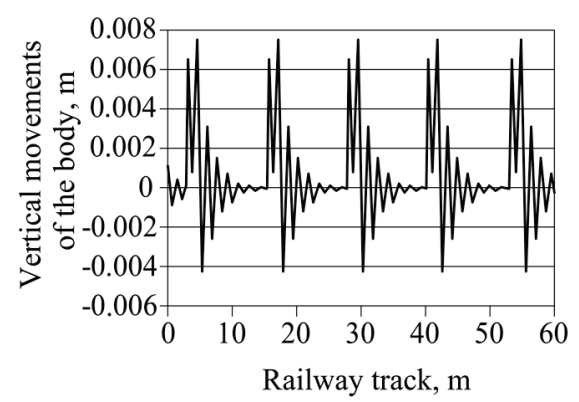

a

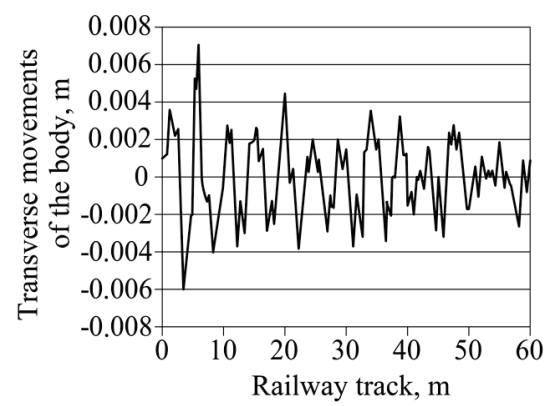

$\mathrm{b}$

Fig. 4. Displacements of the mine car body resulting from chattering and lateral motion while driving along the straightway track with irregularities (forced vibrations): $a, b-$ displacements due to chattering and lateral motion, respectively, $\mathrm{m}$.

As a result, the frequencies convergence of the mine car body forced vibrations at the straightway sections are equal to $1 \mathrm{~Hz}$ and of the mine car body natural vibrations are equal to $1.1 \mathrm{~Hz}$. Consequently, with the frequency of the mine car body forced vibrations at the curved sections equal to $1.33 \mathrm{~Hz}$ and the frequency of the mine car body natural vibrations equal to $1.4 \mathrm{~Hz}$, the resonant mode of vibrations appears, which contributes to the formation of maximum vertical and transversal loads with vertical irregularities equal to $1-2 \mathrm{~m}$.

At the curved track sections with the radii of $30 \mathrm{~m}$, the studied indicators of loading, stability and safety of the mine cars and rail track are significantly higher than that at straightway track sections with irregularities. Complete wheels unloading occurs when the irregularities depth is more than $0.03 \mathrm{~m}$. 


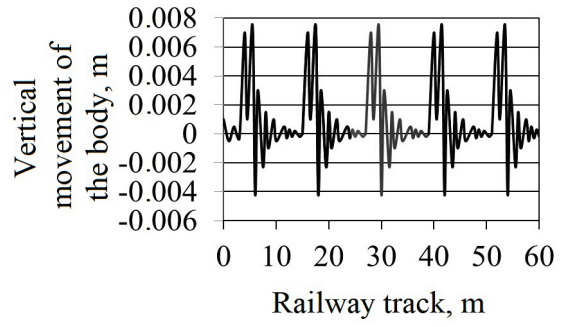

a

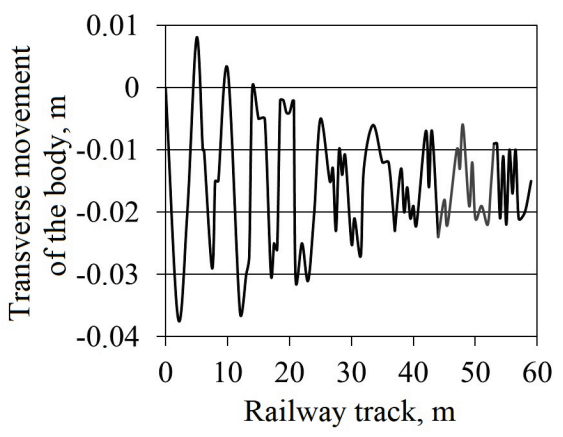

b

Fig. 5. Displacements of the mine car body resulting from chattering and lateral motion while driving along the curved track $(R=30 \mathrm{~m})$ with irregularities (forced vibrations): $\mathrm{a}, \mathrm{b}$ - displacements due to chattering and lateral motion, respectively, $\mathrm{m}$.

Thus, vertical irregularities of the rail track with a length of 1-4 $\mathrm{m}$ and a depth of more than $0.01 \mathrm{~m}$ are the most dangerous for the rail haulage. They should be primarily eliminated in the process of the rail track repairing.

The dependences of loading and safety indicators of the mine car WG-4.5-750 type movement with a speed of $5 \mathrm{~m} / \mathrm{s}$ on the horizontal irregularities with a length of $1-10 \mathrm{~m}$ and a depth of $0.005 \mathrm{~m}-0.006 \mathrm{~m}$ have been determined. It has been revealed that the resonance phenomenon also arises when a length of horizontal irregularities is about $5 \mathrm{~m}$, and as a consequence, the indicators of loading and movement safety have maximum values.

The resonance phenomenon also takes place in the case when the mine car moves with a speed of $3 \mathrm{~m} / \mathrm{s}$ along the track with horizontal and vertical irregularities with length of $3 \mathrm{~m}$, that is, when the ratio of the mine car speed to the length of irregularities is close to the frequency of the mine car natural vibrations. Moreover, the movement safety is not ensured even with a small depth value of irregularities.

The characteristic dependences have been also obtained of the maximum values of the transverse loads and the coefficients of resistance to the rail track shear on the parameters of the horizontal irregularities of the straightway track at a movement speed of $5 \mathrm{~m} / \mathrm{s}$. It has been found that the occurrence of horizontal irregularities with a length of $1-10 \mathrm{~m}$ and a depth of more than $0.01-0.06 \mathrm{~m}$ at straightway and curved track sections leads to a significant increase in indicators of loading, stability and safety of movement. While with irregularities about $5 \mathrm{~m}$ long, a resonance phenomenon occurs at which all indicators correspond to the maximal critical values.

The resonance phenomenon is also possible when the mine car moves at a speed of $3 \mathrm{~m} / \mathrm{s}$ along the track with horizontal and vertical irregularities equal to $3 \mathrm{~m}$. It has been determined that when the mine car moves along the straightway track at a speed of $3 \mathrm{~m} / \mathrm{s}$ and along the curved track section with a radius of $30 \mathrm{~m}$ and at a speed of $4 \mathrm{~m} / \mathrm{s}$ with irregularities of $3 \mathrm{~m}$ long, the forced vibrations frequency is equal to 1.0 and $1.33 \mathrm{~Hz}$ and the natural vibrations frequency is equal to 1.1 and $1.4 \mathrm{~Hz}$, respectively. Therefore, their difference is minimal. However, the movement safety is not ensured even with small depth values of transverse irregularities and the most local extremes of motion modes indicators for the two-axle mine car are approaching to resonance ones.

For the two-axle mine car WG-4.5-750 type, the easement curves influence on the running gears loading and movement safety has also been assessed. Table 3 shows that in the easement curves the loading level of the running gears, rails and spring groups can be significantly higher than that at the straightway and curved track section with a constant 
radius. In addition, it has been revealed that the difference between the results obtained for calculation schemes, in which each wheelset is represented by one or three solids (axle and two wheels), reaches 35-66\% in terms of loading and 35-61\% in terms of movement safety.

Table 3. Dynamic indexes of loading and stability of the two-axle mine car movement along the straightway track section in easement curve and circular curve at a speed of $5 \mathrm{~m} / \mathrm{s}$.

\begin{tabular}{|l|c|c|c|}
\hline \multirow{2}{*}{ Characteristics } & \multicolumn{3}{|c|}{ The radii of curves, $\mathrm{m}$} \\
\cline { 2 - 4 } & $\infty$ & $\infty \ldots . .20$ & 20 \\
\hline Vertical loads on wheels, kN & 67.4 & 80.6 & 73.7 \\
\hline Transverse loads on wheelsets, kN & 13.6 & 33.7 & 34.5 \\
\hline Vertical loads on rails, kN & 69.2 & 81.8 & 75.0 \\
\hline Transverse loads on rails, kN & 17.0 & 36.3 & 35.3 \\
\hline $\begin{array}{l}\text { Vertical loads on the elastic elements of } \\
\text { the mine car buffer springs, kN }\end{array}$ & 15.8 & 80.6 & 74.6 \\
\hline $\begin{array}{l}\text { Transverse loads on the elastic elements } \\
\text { of the mine car buffer springs, kN }\end{array}$ & 4.37 & 23.8 & 21.6 \\
\hline $\begin{array}{l}\text { Coefficients of resistance to wheels } \\
\text { unloading }\end{array}$ & 0.64 & 0.82 & 0.82 \\
\hline $\begin{array}{l}\text { Coefficients of resistance to wheels } \\
\text { railing }\end{array}$ & 4.25 & 2.30 & 1.91 \\
\hline $\begin{array}{l}\text { Coefficients of resistance to the rail track } \\
\text { shear }\end{array}$ & 0.12 & 0.24 & 0.27 \\
\hline
\end{tabular}

Based on the research results (Figures 1-3 and Tables 1-3), it has been determined that short vertical irregularities up to $2 \mathrm{~m}$ in length significantly influence on the load of the track structure made by the mine car. The critical point of load is formed when the irregularities are about of $0.5-1 \mathrm{~m}$ in length and if the depth of the vertical irregularities is within $0.015-0.025 \mathrm{~m}$. In this case, the loads are by $1.5-4$ times higher than the basic ones which are formed by vertical irregularities of $2-10 \mathrm{~m}$ in length and $0.005 \mathrm{~m}$ in depth.

Based on the research result, it has been determined that with an increase in a depth and a decrease in a length of transverse irregularities, the vertical and horizontal loads between the wheel and the rail intensively increase. They can be by $2-10$ times higher than the loads caused by basic small depths and large lengths of the track rails irregularities. The obtained research results confirm the need to regulate the margin tolerances for the rail track maintenance according to the criteria of changing the gauge width, deviations from linearity in the plan and profile of the track rails.

Figure 6 shows the dependences of the safety coefficients on the mine car speed within $2-7 \mathrm{~m} / \mathrm{s}$. The graphs also show the levels of acceptable values of the following coefficients: coefficients of resistance of the mine car wheels to unloading; coefficients of resistance to the track panel shear; coefficients of resistance to wheelsets railing.

Coefficient values should not exceed acceptable safety indicators of $0.7,0.4$ and 1.5 , respectively. The graphs demonstrate that at a speed of more than $3.5 \mathrm{~m} / \mathrm{s}$ at curved track sections, all safety indicators of the mine car movement and the track stability are violated.

Coefficients of resistance to wheels unloading, wheelsets railing and rail track shear reach the maximum acceptable values in case of the mine car speed range of $4-5 \mathrm{~m} / \mathrm{s}$ for the accepted irregularities at the straightway sections. With an increase in the depth parameters and a decrease in a length parameters of vertical and horizontal irregularities, these results have the worst safety indicators of the rail haulage operation. 


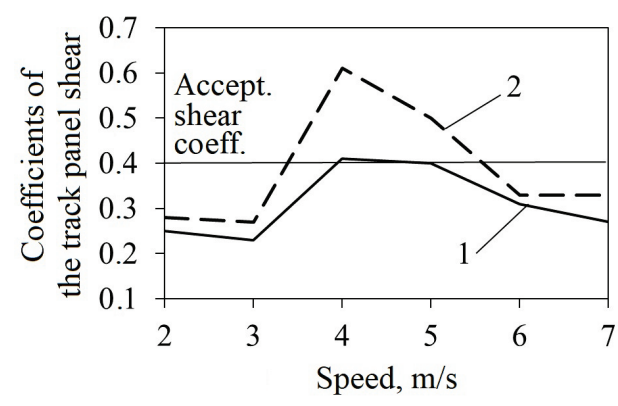

a

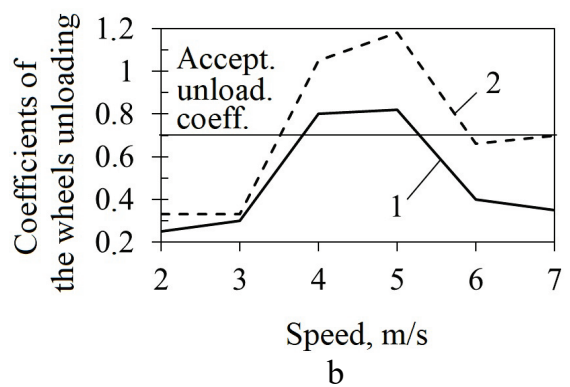

b

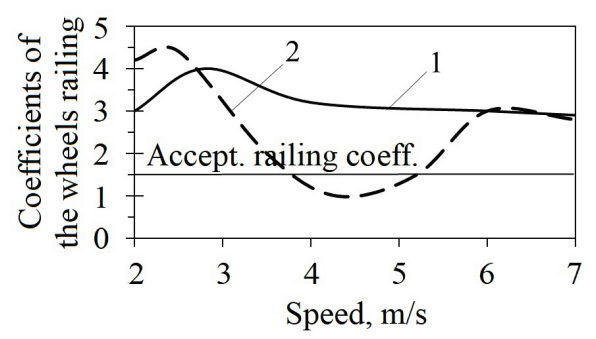

c

Fig. 6. Dependences of extreme values of the transport system elements resistance coefficients on the speed of movement: $\mathrm{a}, \mathrm{b}$, and $\mathrm{c}$ - coefficients of resistance to the track panel shear, wheels unloading and wheels railing, respectively; 1,2- straightway and curved (with a radius of $30 \mathrm{~m}$ ) track sections, respectively.

The above analysis of the nature of loading the elements of the track structure and the mine car, as well as analysis of safety indicators for the rail haulage operation, testifies the importance of margin tolerances normalization for the rail track maintenance according to the parameters of the rail track irregularities in order to ensure the operability and safety of the rail haulage.

\section{Conclusions}

1. The indicators of loading, stability and safety of the two-axle mine cars WG-4.5-750 type movement along the rail track with straightway and curved sections of the trajectory and significant deviations along the irregularities of the track rails in horizontal and vertical planes have been determined.

2. It has been determined that the difference between the results obtained for calculation schemes in which each wheelset is represented by one or three solids (axle and two wheels) reaches $35-66 \%$ in terms of indicators of loading and 35-61\% in terms of the safety of the mine car movement along the rail track.

3. It has been found that the vertical irregularities are the most dangerous for the safety conditions of the mine car movement according to indicators of wheels unloading, wheelsets railing and the track panel shear. Critical conditions are when vertical irregularities have a length less than $3 \mathrm{~m}$ and a depth more than $0.015 \mathrm{~m}$, and when horizontal irregularities have a length less than $4 \mathrm{~m}$ and a depth more than $0.02 \mathrm{~m}$. These irregularities should not occur during operation, hence, they should be eliminated in a timely manner. They should also be regulated in the rules and requirements for the design, operation and current maintenance of the rail haulage.

4. It has been found that at the curved rail track sections when the two-axle mine car moves with a speed of more than $3.5 \mathrm{~m} / \mathrm{s}$, all the movement safety indicators are violated. 
At the straightway rail track sections, these safety indicators are violated at a speed range of 4-5 m/s. The critical level of loading is formed when irregularities are of $0.5-1 \mathrm{~m}$ in length and $0.015-0.025 \mathrm{~m}$ in depth and exceed the permissible level by $1.5-4$ times. This creates an emergency event of the mine car movement.

5. The obtained graphical dependences of the indicators of loading and safety of the mine car movement at a speed of $5 \mathrm{~m} / \mathrm{s}$ on the irregularities with a length of $1-10 \mathrm{~m}$ and a depth of $0.005-0.060 \mathrm{~m}$, have revealed that the resonance phenomenon occurs with a length of horizontal irregularities of $5 \mathrm{~m}$. The resonance phenomenon also occurs when the mine car moves at a speed of $3 \mathrm{~m} / \mathrm{s}$ along the track with horizontal and vertical irregularities of about $3 \mathrm{~m}$ in length, that is, when the ratio of the mine car speed and the length of the irregularities corresponds to the mine car natural vibrations. This does not ensure the safety of the mine car movement even at small depths of horizontal irregularities.

6 . The research results can be used when preparing regulatory-technical documentation for the construction, current maintenance and repairing of the railway track according to the criteria of margin tolerances on the rail track irregularities and the mine cars speed, as well as for construction of new rolling stock and track structure.

\section{References}

1. Melnikov, S.A., Budishevskiy, V.A., Berezhinskiy, V.I. (2009). Sovershenstvovanie deystvuyushchikh i sozdanie novykh shakhtnykh lokomotivov. Ugol Ukrainy, 5, 12-15

2. Berezhinskiy, V.I,. Babakov, S.V. (2012). Novye razrabotki dlya povysheniya bezopasnosti rabot na shakhtnom relsovom transporte i podeme. Ugol Ukrainy, 6, 17-20

3. Debelyy, V.L. (2009). Modernizatsiya shakhtnykh lokomotivov v tselyakh ikh nadezhnosti i bezavariynosti. Ugol Ukrainy, 4, 4-6

4. Budishevskiy, V.A., Melnikov, S.A. (2005). Obosnovanie menendzhmenta kachestva shakhtnykh lokomotivov. Ugol Ukrainy, 4, 15-17

5. Melnikov, S.A., Berezhinskiy, V.I., Samoylov, A.I (2012). Obosnovanie napravleniy razvitiya kolesnogo transporta. Ugol Ukrainy, 8, 34-37

6. Peysakhovicha, G.Ya., Remizova, I.P. (1985). Podzemnyy transport shakht i rudnikov. Moskva: Nedra

7. Voloshyn, O., Riabtsev, O. Some important aspects of rock mechanics and geomechanics. E3S Web of Conferences. International Conference Essays of Mining Science and Practice, 109 (2019). https://doi.org/10.1051/e3sconf/201910900114

8. Govorukha, V.V. (2013). Sovershenstvovanie relsovogo puti i strelochnykh perevodov podzemnogo transporta. Ugol Ukrainy, 3, 44-49

9. Ivanov, O.I. (1999). Otsenka professionalnogo riska travmirovaniya shakhterov. Ugol Ukrainy, 11, 46-47

10. Fedoriachenko, S.O. (2012). Matematychna model shakhtnoi vahonetky. In: Forum hirnykiv - 2012: Materialy mizhnarod. konf., 108-114

11. Novikov, E.E., Zemlyanoy, E.F., Govorukha, V.V. (1983). Dinamika i prochnost shakhtnykh transportnikh sosudov. Kiev: Nauk. dumka

12. Lazaryan, V. A. (1985). Dinamika transportnykh sredstv. Kiev: Nauk. dumka

13. Verigo, M.F., Kogan, A.Ya. (1986). Vzaimodeystvie puti i podvizhnogo sostava. Moskva: Transport

14. Radchenko, V.A. (1986). Krivolineynoe dvizhenie relsovykh transportnykh sredstv. Kiev: Nauk. dumka

15. Hovorukha, V. Movement stability of vehicles with a rigid and free wheels mounting on wheelset axles. E3S Web of Conferences. International Conference Essays of Mining Science and Practice, 109 (2019). https://doi.org/10.1051/e3sconf/201910900029

16. Hovorukha, V. Studying and improving intermediate rail fastening of rail transport. 
E3S Web of Conferences. International Conference Essays of Mining Science and Practice, 109 (2019), https://doi.org/10.1051/e3sconf/201910900028 